\title{
ON THE OBITUARY OF THE DOHA ROUND: A PATH FOR REINVENTING THE WTO'S FUTURE
}

\author{
DR. ${ }^{*}$ DESTAW A. YIGZAW
}

Assistant Professor in Law, Modern College of Business and Science (Oman)

\section{ABSTRACT}

The World Trade Organization is in decline. Its dispute settlement mechanism faces an existential crisis. The Doha Round is all but dead. While many factors have contributed to the decline of the WTO, most can be traced to its design flaws. With the adoption of the Marrakesh Agreement, the scope of the multilateral trade regime expanded. However, such expansion was pointedly selective. While business and corporate interests were protected through the incorporation of traditionally nontrade subjects, such as intellectual property and investment, social and development issues remain sidelined. As a result, many came to view the WTO as an agent of neoliberalism spearheading the diversion of the wealth of nations into the wealth of corporations. Such single-minded pursuit of profit has not only undermined the legitimacy of the WTO but also has contributed to the creation a conducive environment for the rise of nationalism, populism, and protectionism, threatening liberal international order.

KEYWORDS: World Trade Organization, dispute settlement mechanism

Received: Mar 18, 2021; Accepted: Apr 08, 2021; Published: May 13, 2021; Paper Id.: IJPSLIRJUN20213

\section{INTRODUCTION}

The World Trade Organization (WTO) is in decline. Its renowned dispute settlement mechanism faces an existential crisis. With the U.S. blocking the appointment of new judges, and the term of the last remaining judge having expired in November 2020, the Appellate Body (AB) has currently no judges. The Doha Round is all but dead. ${ }^{1}$ The organization's ability to address trade issues and resolve trade dispute has generally waned. What went wrong with the WTO?

The most boisterous assault to the multilateral trading system came from former President of the United States, who not only started a trade war with China and other nations, in total disregard of WTO rules, but also strangled the Appellate Body. Some may hope that the change in the U.S. administration would help revive the WTO's authority. However, the WTO was on a downward spiral far long before Trump's rise to power. Trump's attack on the WTO is a consequence of the constitutional defects of the institution, not its cause. The Great Recession may also have made governments more cautious, and the case for liberalizationless alluring. Yet, again,

*Assistant Professor in Law, Modern College of Business and Science (Oman); destaw.yigzaw@mcbc.edu.om

${ }^{1}$ That means not a single round of trade negotiations has come to conclusion under the WTO. Compare that to the successful rounds concluded under the auspices of its predecessor, i.e., the GATT.As a matter of fact, having failed to the Doha Round, WTO members have long turned towards regional and transcontinental trade alliances, the most no of which is the Trans-Pacific Partnership (TPP). 
the WTO was struggling long before the Great Recession. ${ }^{2}$ It's also easy to point to the shift in the North-South trade (in)balance, particularly the rise of China as a global trading powerhouse. ${ }^{3}$ However, while the world is no longer unipolar, it must be remembered that when tens of thousands of labor rights activists, environmentalists, and anti-poverty campaigners rocked the streets of Seattle in late 1999, protesting against the Third WTO Ministerial Conference, China had yet to accede to the WTO. ${ }^{4}$ What animated protestors was rather the conviction that the WTO represented the ascendance of corporate power over social and environmental concerns.

The WTO's legitimacy deficit, which is its primary political and operational handicap, I would argue, runs deep into its design. The recent wave of populism, nationalism and concomitant protectionism stem in part from the malaise in neoliberal trade policy. With the adoption of the Marrakesh Agreement, the scope of the multilateral trade regime expanded by leaps and bounds. ${ }^{5}$ As a result, not only the effects of trade, but also the rules of international trade now cut across traditionally nontrade spheres. ${ }^{6}$ Trade rules now influence domestic policy more than ever before. Such expansion was, however, pointedly selective. While business and corporate interests were protected through the incorporation of traditionally nontrade subjects, such as intellectual property and investment into the WTO at the Uruguay Round, social and development issues remain sidelined. That broke with the post warpolicy of embedded liberalism. With the creation of the WTO, social and development issues have effectively been displaced by corporate interests.

This Article argues that restoring the legitimacy of the WTO requires nothing short a radical reconfiguration of global trading system. Part II demonstrates why the theory of comparative advantage is an inadequate justification for trade liberalization. ${ }^{7}$ It argues that WTO rules are tailored to corporate interests in much the same fashion the mercantilist system, as Adam Smith described it, was tailored to the interests of merchants and manufacturers. Part III maintains that the creation of the WTO marked a retreat from the postwar vision of harmonizing trade with development and employment issues. Part IV suggests a possible path for reorienting the WTO.

\section{JUSTIFYING TRADE LIBERALIZATION}

The case for free trade is not self-evident, or if it is, how free it should be is not. Thus, addressing the basic question of why

${ }^{2}$ The deadline for the conclusion of the Doha Round had already been missed, and it was already palpable that its revival needed a miracle Bhala writes: 'following the July 2008 collapse...only truly optimistic trade souls could keep faith in the resurrection of the Doha Round.' Raj Bhala, Resurrecting the Doha Round: Devilish Details, Grand Themes, and China Too, 45 Tex. Int'1 L.J. (2009) 9.

3 See, for example, Kristen Hopewell, Breaking the WTO: How Emerging Powers Disrupted the Neoliberal Project (Stanford University Press, 2015); see also generally William Jannace and Paul tiffany, A New World Order: The Rule of Law, or the Law of Rulers? 42 Fordham International Law Journal (2019).

${ }^{4}$ The Third Ministerial Conference that convened in Seattle at the end of 1999 was set to launch a new round of trade negotiations (the first within the WTO framework) that, if launched, would have been called the 'Millennium Round.' Disagreements on major trade negotiations compounded by a massive and violent protest (widely known as 'Battle of Seattle') meant that the launching of a new round of trade negotiations had to wait until 2001. See also generally Clyde Summers, The Battle in Seattle: Free Trade, Labor Rights, and Societal Values, 22 U. Pa. J. Int'1 Econ. L (2001).

${ }^{5}$ While the GATT dealt only with trade in goods, the WTO's discipline extends to diverse substantive subject areas; from trade in services to intellectual property and trade-related investment measures; from agriculture to sanitary and psytosanitary measures, from technical standards to customs valuation, from preshipment inspections to rules of origin and import licensing, etc. See generally Sharif Bhuiyan, National Law in WTO Law: Effectiveness and Good Governance in the WTO System (Cambridge, 2007) 3-4.

6 Francesco Francioni, Environment, Human Rights and the Limits of Free Trade, in Francesco Francioni(ed.) Environment, Human Rights and International Trade (Hart Publishing, Oxford and Portland, Oregon, 2001$) 1$.

${ }^{7}$ To be sure, the theory of comparative advantage provides a compelling economic case for free trade. However, the legitimacy of any system must ultimately be judged by reference to its consequence to the lives of people, and the theory of comparative advantage shows almost nothing about how the actual lives of people go. 
it should be liberalized is the point of departure for any discussion about international trade. Nobel Laureate Paul Samuelson provides a representative summary of economic arguments for free trade. He writes: 'there is essentially only one argument for free trade or freer trade, but it is an exceedingly powerful one: Free trade promotes a mutually profitable regional division of labor, greatly enhances the potential real national product of all nations, and makes possible higher standards of living all over the globe. ${ }^{8}$ That is the central premise underpinning the establishment of theWTO. ${ }^{9}$

There is little dispute over the economic virtues of free trade. There is profound disagreement, however, on whether WTO trade proceeds in accordance with the stated goals. Also, to argue that free trade can helpenhance the economic welfare of nations is one thing; whether it is enhancing the standards of living of people equitably is something else altogether. But one thing is clear: the economic argument with which the WTO reckons is not based on some intrinsic value of free trade. It is rather based on the instrumental value of free trade in improving the standards and conditions of human life. Economic arguments are consequentialist. ${ }^{10}$ Hence, the way free trade is pursued must be judged entirely by its consequence on the lives of people.

Unarguably, trade is a means to an end. Expanding trade may help maximize wealth. Yet, wealth is 'merely useful as a means to something else. ${ }^{11}$ While comparative advantage explains why liberalization may spur economic growth, it does not show how aggregate economic welfare thus derived ensures that people eat enough and better, live longer and healthier, enjoy more freedom, and engage in activities that, to borrow from Samuelson 'convert existence into living: education, travel, recreation, and charity,'among others, which standard of living - ostensibly the central goal of the WTO - entails. ${ }^{12}$ It is these noneconomic goals that provide the ultimate justification for trade liberalizations. Hence, if the WTO is true to its stated goals, it seems an imperative to look beyond economic theories and connect meansand end in a more tangible way.

David Ricardo's theory of comparative advantage is invariably invoked as the economic rationale for free trade. ${ }^{13}$ The essence of this theory is that free trade enhances aggregate economic welfare by promoting a mutually beneficial international division of labor. Ricardo was by no means the first to champion the cause of free trade. Other pioneers, most notably Adam Smith, had already shaken the theoretical underpinnings of the mercantilism and laid down a solid foundation for liberal trade. ${ }^{14}$ Adam Smith's criticism of mercantilism can be viewed at least from two vantage points. One, Smith refuted mercantilism as uneconomical. Two, he argued that mercantilismwas an extractive system crafted and

\footnotetext{
${ }^{8}$ Paul A. Samuelson, Economics (11 ${ }^{\text {th }}$ ed., McGraw-Hill International Book Company, 1980) 651. Emphasis added

${ }^{9}$ See the opening paragraph of the preamble of the Marrakesh Agreement Establishing the World Trade Organization (15 April 1994).

${ }^{10}$ Sen defines consequentialism as a component of utilitarian moral theorythat judges the rightness of actions and choices 'entirely by the goodness of the consequent state of affairs.' Amartya Sen, Resources, Values and Development (Harvard University Press, Cambridge, Massachusetts, 1984) 278.

${ }^{11}$ Unlike virtue or happiness, which are desirable for their own sake, 'wealth evidently is not the good of which we are in search, for it is merely useful as a means to something else.' Aristotle, The Nicomachean Ethics (5th ed., Kegan Paul, Trench, Trubner \&Co, London, 1893) 8.

${ }^{12}$ See generally, Samuelson, supra $\mathrm{n} 8$ at75.

${ }_{13}$ Although Ricardo's theory of comparative advantage, based on a simple two nations-two commodities -model has its own limitations, the WTO reckons that since no country is without comparative advantage, every country stands to benefit from free trade. According to the WTO, even a country that is good 'at making bread' may fare well trading with a country that is more efficient 'at making automobiles.' WTO, The Case for Open Trade: http://www.wto.org/english/thewto_e/whatis_e/tif_e/fact3 e.htm

${ }^{14}$ See generally Leonard Gomes, The Economics and Ideology of Free Trade: A Historical Review (Edward Elgar, Cheltenham, UK., 2003).
} 
sustained by powerful traders and manufacturers who seek to maximize their business interests at the expense of the society. ${ }^{15}$ In other words, Smith observed that mercantilism was inimical to social justice.

\section{A. Economic Rationale}

Adam Smith refuted the doctrine of mercantilismas, inter alea, an uneconomical. He provided a compelling explanation of how nations may mutually benefit from engaging in free trade. He argued that since each country is endowed with unique conditions of production, each could benefit from capitalizing on what it can produce best and trade with others. Therefore, he maintained, free trade would lead to an efficient international division of labor by convincing each nation to specialize in the production of commodities in which it has absolute advantage.$^{16}$ Typically, Smith's Wealth of Nations is invoked to justify the economic virtues of free enterprise. Yet, Smith's arguments suggest much deeper virtues of liberal trade than just profit maximizations. Smith recognized that absolute free trade was neither feasible nor desirable. ${ }^{17}$

\section{B. Fair Opportunity for All}

'To us the Wealth of Nations is so obviously the first ever book of economics that it is natural to go through trying to pick 'the economics' out of it and forget the rest,' observes Parker. ${ }^{18}$ Indeed, whereasconcepts such asliberal internationaltrade, laissez faire domestic economic policy, or 'invisible hand' of the market, are almost intuitively associated with Smith's Wealth of Nations, extra-economic dimensions of the book are undertheorized and less known. However,the Wealth of Nations is not a book of economics; it is a book of political economy. It does not treat trade (or economics, for that matter) as an isolated realm. Far from that, it discusses free trade from the perspective of sociopolitical goals ranging from socioeconomic equity and stability to international harmony. ${ }^{19}$ In other words, in Wealth of Nations, economic and trade issues are 'embedded' in social and political relations. Also, while Smith argued for freedom of trade, he never viewed commercial pursuit as unmixed blessing. On the contrary, he argued with equal vigor that in the pursuit of their business interests, traders might threaten social welfare. In much similar way that multilateral corporations are accused today of influencing governments and intergovernmental organizations such as the WTO, Adam Smith was unrestrained in criticizing merchants and manufacturers, who, he argued, were intent to highjack state power to promote their narrow business interests. Smith held that traders would seek to maximize profit even when that entails dire social consequences, like exporting grain at a time when there is acute famine at home. ${ }^{20}$

\footnotetext{
${ }^{15}$ Adam Smith, An Inquiry into the Nature and Cause of the Wealth of Nations (Maruzen Company Limited, Tokyo, 1776/1940) at 626.

16“'It is the maxim of every prudent master of a family, never to attempt to make at home what it cost him more to make than to buy. The tailor does not attempt to make his own shoes, but buy them of the shoemaker. The shoemaker does not attempt to make his own clothes, but employs a tailor. The farmer attempts to make neither the one nor the other, but employs those different artificers. All of them find it for their interest to employ their whole industry in a way in which they have some advantage over their neighbors, and to purchase with a part of its produce." Id at 424.

${ }^{17} \mathrm{He}$ identified certain scenarios where economics should give way to greater values. He, for example, argued, that defense being the first duty of a state, trade distorting measures are justified regardless of the economic cost. He also warned that liberalization should take place gradually so as not to affect the employment and livelihood of people all at once.Smith, supra n 15 at 429-36.

18 Noel Parker, Look, No Hidden Hands: How Smith Understands Historical Progress and Social Values, in Stephen Copley and Kathryn Sutherland (eds.), Adam Smith's Wealth of Nations: New Interdisciplinary Essays (Manchester University press, Manchester, 1995) 122.

${ }^{19}$ See generally David McNally, Political Economy and the Rise of Capitalism: A Reinterpretation (University of California Press, Berkley, 1988) 158; see also Gomes, supra n 14 at 35.

${ }^{20}$ Adam Smith argued that the motive of traders being to maximize profit both in times of plenty and scarcity, they may go as far as destroying a portion of the crop to keep the price high. Smith, supra n 17 at 491-2.
} 
Adam Smith was concerned as much for fairness as for freedom. He advocated for the wealth of a nation shared among the people, as opposed to one monopolized by the powerful few. ${ }^{21}$ Beyond the question of what kind of trade policy best promotes national economic growth, the issue of how economic gains are distributed is central in his criticism of mercantilism. He provided extensive expositions of the conflict of interest between that of wealthy traders and manufacturers on the one hand and of the public on the other. He reiterated the threat powerful merchants pose to the interests of workers, smaller merchants, consumers, the integrity of the market system, and by extension, to the overall socioeconomic prosperity. ${ }^{22}$

The Wealth of Nations rigorously rejects a market system dominated by few powerful merchants and manufacturers (corporate interests of the time) that could influence government legislation. What it advocates is a market system that offers a fair chance for all. ${ }^{23}$ Contrary to the conventional depiction of Smith as an advocate of minimal state presence in the economy, he argued that the state should maintain command over the marketplace- put a check on powerful traders and ensure fair competition. ${ }^{24}$ Smith argued that the mercantile system was animated by merchants, who would constantly strive to monopolize the market by twisting the state machinery or even in violation of the law. ${ }^{25}$ Hence, a free trade in which not only the rich and the powerful, but also 'the poor and the indigent' could benefit logically requires checking the monopolistic derives of merchants. The kind of free trade Adam Smith envisaged was not, therefore, unregulated trade. It presupposes a government that is capable of protecting the interest of the society against powerful traders so that the productive efficiency of free trade can be harnessed towards social ends. ${ }^{26}$ It is thus fair to conclude that Adam Smith observed twin virtues of free trade. One, free trade spurs economic growth; and two, free trade advances distributional parity by neutralizing the monopolistic propensity of powerful merchants (the Amazons and the Googles of the time).

The crucial question here is this: does the WTO system embrace the above twin virtues of free trade as powerfully articulated by Adam Smith? The answer to this question depends, among other things, on whether or not the WTO rules are tailored to the interests of powerfulcorporations, rather than the peoples of the world; whether or not powerful

\footnotetext{
${ }^{21}$ See generally Asbjorn Eide, The Importance of Economic and Social Rights in the Age of Economic Globalization in Wenche Barth Eide and Uwe Kracht (eds.), Food and Human Rights in Development: Legal and Institutional Dimensions and Selected Topics (V.I, Intersentia, Antwerpen, Oxford, 2005) 18.

22 "It cannot be very difficult to determine who have been the contrivers of this whole mercantilist system; not the consumers, we may believe, whose interest has been entirely neglected; but the producers whose interest has been so carefully attended to; and among this latter class our merchants and manufacturers have been by far the principal architects. In the mercantile regulations...the interests of our manufacturers have been most peculiarly attended to; and the interest, not so much of the consumers, as that of some sets of producers, has been sacrificed to it."

Smith, supra n 15 at 626.

${ }^{23}$ Heinz Lubasz, Adam Smith and the 'Free Market', in Copley and Sutherland (eds.), supra n 18 at 52.

24 "It is not by their work, but by the complete work of the weavers, that our great master manufacturers make their profits... By extorting from the legislature bounties upon the exportation of their own linen, high duties upon the importation of all foreign linen, and a total prohibition of the home consumption of some sorts of French linen, they endeavor to sell their own goods as dear as possible... They are as intent to keep down the wages of their own weavers, as the earnings of the poor spinners, and it is by no means for the benefit of the workman... It is the industry which is carried on for the benefit of the rich and the powerful, that is principally encouraged by our mercantilist system. That which is carried on for the benefit of the poor and the indigent is too often, either neglected, or opposed."
}

Smith, supra n 15 at 609.

${ }^{25}$ Smith, supra n 15 at 491-2.

${ }^{26}$ See generally McNally, supra n 19 at 256. 
corporations influence the rules and operations of the WTO (in much the same way as powerful traders and manufacturers influenced government policies during Adam Smith's time); whether or not concrete mechanisms are in place to ensure not only that trade is liberalized but also that the fruits of free trade are distributed equitably; and whether or not the rights and interests of those who have little or no influence on the course of trade are taken into account.

\section{A Retreat from Embedded Liberalism}

In the aftermath of WWII, peace was the overriding global agenda. The multilateral trading architecture was designed as part of the overall strategy for peace and stability. ${ }^{27}$ It was agreed that free and fair trade would makethe world prosperous and safer too. That means the traditional economic case for free trade is now backed by an even more compelling international public policy_-peace. ${ }^{28}$ The postwar trading system was informed by what is known as 'embedded liberalism.' ${ }^{29}$ Virtually all the political foundations for the postwar order-from the 'bilateral' Atlantic Charter to the universal United Nations (UN) Charter and the ill-fated Havana Charter-envisage comprehensive approach to socioeconomic issues, and establish responsibilities for states to cooperate. ${ }^{30}$ Imperatives of domestic order and tranquility in the face of postwar social desperation and communism in the East required adequately addressing social issues within the framework of market liberalism. ${ }^{31}$ With respect to labor rights in particular, the International Labor Organization (ILO) had, from the beginning, maintained that 'universal peace can be established only if it is based upon social justice. ${ }^{32}$

\section{A. The International Trade Organization (ITO)}

The UN Charter envisions an international order where states strive to address problems of economic, social, cultural or humanitarian character through cooperation. It also establishes the basic institutional framework necessary to achieve those goals. In addition to the principal organs it establishes, the Charter envisages the establishment of various specialized agencies that are aimed at facilitating international cooperation. ${ }^{33}$ The Charter entrusts the Economic and Social Council (ECOSOC) with the task of coordinating the various specialized agencies of the UN, among other things. ${ }^{34}$ In its very first

\footnotetext{
${ }^{27}$ Although wars are almost a constant in the history of human civilization, the level of destruction caused by WWII has made the preservation of peace a top priority. Interestingly, the imperative for an effective cooperation to maintain international peace and liberal trade agenda coincided with the interests of the main architect of the post-war order, the USA, which not only emerged as the indisputable military superpower but also produced around half of the world's goods at the time. See generally Micheline R. Ishay, The History of Human Rights: From Ancient Times to the Globalization Era (University of California Press, Los Angeles, 2004)174-179.

${ }^{28}$ There is not much novelty in the recognition of the relations between trade and peace. Classical thinkers have articulated that greater freedom in the pursuit of commerce would provide a secure foundation for international peace, stability and prosperity"The natural effect of commerce is to bring about peace. Two nations that trade with each other become reciprocally dependent; if one has an interest in buying, the other has an interest in selling, and all unions are founded on mutual needs." Montesquieu, The Spirit of Laws (Cambridge University Press, 1748/1989) 338

${ }^{29}$ See Robert Howse and Brian Langille, The World Trade Organization and Labor Rights: Man Bites Dog, in Virginia A. Leary and Daniel Warner (eds.), Social Issues, Globalization and International Institutions (Martinus Nijhoff Publishers, Leiden, Boston, 2006) 157.

${ }^{30}$ The Atlantic Charter, for instance, sought to "further the enjoyment by all states, great or small, victor or vanquished, of access, on equal terms to the trade and to the raw materials... [and] bring about the fullest collaboration between all nations in the economic field with the object of securing, for all, improved labor standards, economic development and social security. See points 4, 5, Atlantic Charter (August 14, 1941).

31 The Russian Revolution of 1917 is considered as one of the practical reasons for the establishment of the ILO in 1919. Western governments felt the need to neutralize distributional tensions through the creation of an international organization that would promote labor interests.

${ }^{32}$ See Preamble, the ILO Constitution (1919): http://www.ilo.org/ilolex/english/constq.htm

${ }^{33}$ Art 57, 59, the UN Charter.

${ }^{34}$ Arts 60, 62(1), 63(2),64(1), the UN Charter.
} 
meetingon February 18, 1946 ECOSOC adopted a resolution calling for an international conference on trade and employment. ${ }^{35} \mathrm{~A}$ series of negotiations culminated in 1948 with the adoption of the ITO Charter in Havana, Cuba. The Havana Charter, which is the Final Act of the UN Conference on Trade and Employment, envisioned an organization (i.e., ITO) that would comprehensively deal with trade, employment and development issueswithin the UN framework. The ITO never came into existence mainly because the US Congress did not ratify it(although it was the USA that submitted the initial draft). ${ }^{36}$

\section{B. WTO, not a Delayed ITO}

The WTO is radically different from the ill-fatted ITO. Institutionally, the WTO (unlike the ITO, which, if it came to life, would have been a UN specialized agency) was created outside of the UN framework. Substantively, employment and development issues envisioned in the original ITO agenda, were effectively left out of the operative rules of WTO. By contrast, all of the so-called new issues added into the multilateral trading regime at the Uruguay Round, i.e. TRIPS, traderelated investment measures (TRIMS), and trade in services represent the longstanding interests and aspiration of rich nations, and were by and large outcomes of corporate lobbying power. ${ }^{37}$

Of these, the TRIPS has provoked the most pronounced public anger. Technically,TRIPS commitmentsare not about trade per se; they are about 'trade related' issues of intellectual property (IP) rights. Thus, rights advocates ask: if IPis included as part of the WTO deal, then why not labor rights? That is even more puzzling in view of the fact that labor rights have more intimate and historical connections to trade than IP. ${ }^{38}$ Second, the TRIPS Agreement is not even about liberalization; it is the contrary-monopoly rights protection. As a result, it does not generally lend itself to some of the compelling justifications of free trade. Also, while technology transfer has always been considered as one of benefits of free trade, many believe, the TRIPS Agreement reinforces the prevailing 'knowledge gap.'39 Third, the IP, pharmaceutical patentsin particular, have life and death consequences for the world's poor. ${ }^{40}$

\section{REINVENTING THE WTO}

Discontents against the WTO-led trade are complex and multifaceted. Generally, however, the debate goes in two related arenas. At the state level, there is a heightened difference among member states, as shown by the dismal failure to conclude Doha Round. Both developing countries that feel disadvantaged by past agreements and industrialized nations who have lost millions of jobs as their corporations moved their productions abroad (and as a consequence are facing social and political backlash at home), find it difficult to make any further concessions. On the contrary, some members are reverting

\footnotetext{
${ }^{35}$ UN ECOSOC Res. 13, UN Doc. E/22 (1946).

36 As the ITO Charter was being negotiated, a related, albeit less ambitious, negotiation resulted in one of the most remarkable agreements, the General Agreement on Tariffs and Trade (GATT). Although the ITO was meant to serve as an umbrella institution which would administer the GATT and other issues enshrined in its Charter, the GATT had already entered into force by virtue of the Protocol of Provisional Application (PPA) prior to the Havana Conference. As a result, while the failure of the ITO project kept social and development issues largely at bay, GATT would prove to be a remarkable document and de facto institution for decades until it eventually evolved into the WTO in 1995.

${ }^{37}$ SeeJohn H. Jackson, The World Trading System: Law and Policy of International Relations (2 ${ }^{\text {nd }}$ ed., The MIT Press, Cambridge, Massachusetts, London, 1997)305-317.

${ }^{38}$ The WTO dissociates itself from labor issues, claiming that it is the domain of the International Labor Organization (ILO). But this begs a question since IP is also the province of the World Intellectual Property Organization (WIPO).

39 See generally Joseph E. Stiglitz and Andrew Charlton, Fair Trade for All: How Trade can Promote Development (Oxford University Press, Oxford, New York, 2005) 141-6.

${ }^{40}$ Holger Hestermeyer, Human Rights and the WTO: The Case of Patents and Access to Medicines (OxfordUniversity Press, 2007)11
} 
back to protectionism, as the recent US-China tit-for-tat tariffs have demonstrated. Among the general public, there has always been skepticism of the WTO, which many viewas a symbol of global inequalities that spearheads the diversion of the wealth of nations into the wealth of corporations. ${ }^{41}$

\section{A. From Mercantilist Competition to Cooperation}

The WTO is statist in structure. As such, there is veritable mercantilist competition among member states who seek to expand their respective exports and minimize their imports by engaging in all sorts of trade distorting practices. In some sectors, such as agricultural trade (in which poorer member states have comparative advantage), protectionism and trade distortingpractices (such as domestic support and even export subsidy)are norms rather than exception. ${ }^{42}$

Historically, developing countries had little influence in shaping trade rules. Despite a onenation, onevote system, the requirement of unanimity means that negotiations were more important than the actual voting. ${ }^{43}$ And given their limited market share, they always had limited leverage around the negotiating table. ${ }^{44} \mathrm{As}$ a result, substantive trade rules are lopsided against the interests developing countries. The very culture of negotiation at the WTO excludes many members from 'important aspects of deal-brokering' that take places in the 'green room. ${ }^{45}$ The Uruguay Round that created the WTO was not any different, as it was largely an outcome of a political struggle between the US and the European Community (EC). ${ }^{46}$ And member states are driven by a mercantilist competition to maximize export and limit imports, as the current trade war between the world's biggest economic powers demonstrates. The keen derive for national wealth aggrandizement at all costs is all but palpable. That explains the elevation of profit over human lives, as evidenced bythe opposition to a temporary waiver of IP rights to facilitate global access to COVID-19 vaccines. It must be acknowledged, therefore, that the WTO carries the vestiges of mercantilism. Indeed, the WTO's modus operandi mirrors more of mercantilism than the alluring goals stated in its own Preamble.

It's an imperative, therefore, that WTO rules are reconciled with the classical justifications for free trade, as advocated by the likes of Adam Smith as well as organization's own stated goals. That requires reconfiguring the WTO system away from neoliberalism and embracing embedded liberalism, along the lines of the original postwar vision. It requires addressing the historical disadvantages of developing nations, especially in labor intensive products, such as agriculture. It means reconsidering whether non-trade issues, such as the TRIPS and TRIMS belong in the WTO or at least reconciling them with the socioeconomic obligations of member states. It also means incorporating core labor standards and environmental considerations, which goes a great length in addressing the longstanding demands of industrialized nations.It takes reconciling GATT/WTO agreements to the realities of the $21^{\text {st }}$ century. Absent meaningful reforms, member states are likely to continue to look away to regional trade alliances, further undermining the WTO.

\footnotetext{
${ }^{41}$ See Eide, supra $\mathrm{n} 21$ at 18.

${ }^{42}$ See Destaw A. Yigzaw, WTO Agricultural Trade and the Unfulfilled Promise of Development, 11 (2) South Carolina Journal of International Law and Business 163-225(Spring 2015)

${ }^{43}$ See generally Stephen Zamora, Voting in International Economic Organizations, 74 A.J.I.L. (1980) 580

${ }^{44}$ See generally Robert E. Hudec, Developing Countries in the GATT Legal System (Trade Policy Research Center, London, 1987).

45 'The negotiating culture of the GATT served to exclude numerous Members from important aspects of deal-brokering. Policies and treaties were negotiated in notorious 'Green Room' meetings to which only certain Members were invited, and in which discussions were secret. Green Room decisions were then presented to other Members as faits accomplis.' Sarah Joseph, Blame it on the WTO? A Human Rights Critique (Oxford University Press, New York, 2011) 63; see also UNDP, Human Development Report: Deepening Democracy in a Fragmented World (New York, 2002) 118.

${ }^{46}$ Jackson, supra n 18 at 314 .
} 


\section{B. From Wealth of Nations to Wealth of the People}

It is unarguable that trade liberalization has dispossessed many of their livelihoods. Millions of workers in rich countries have fallen victims of deindustrialization (dealing a blow to their economic security and self-esteem).Competitiveness exigencies and the quest for profit means their counterparts in poor countries often work under appalling conditions for low wages. Corporation that move their production abroad have little or no obligations either to the workers they leave behind nor to those in their new destinations. Innumerable small businesses and small holding farmers who are unable to cope with cheap imports have been driven out of the market as a result of trade liberalization. ${ }^{47}$ The quest for competitiveness and the diminished role of the states in the economy (which WTO membership requires) means their policy options and practical ability to safeguard those who are left behind are limited. Importantly, while the WTO was deliberately created outside of the UN framework, how its complex legal regime fits into the broader corpus of public international has not been articulated, apparently out of policy choice than oversight. As result, WTO members are reluctant to abrogate from their WTO obligations even when their socioeconomic obligations call for action. That is precisely why even when it's a matter of life and death for millions, developing countries are only hoping for the WTO to grant them temporarily waiverof their TRIPS obligations to provide desperately needed vaccines to the COVID-19 virus. Their hope looks misplaced, as the proposal was met with resistance from wealthy nations. ${ }^{48}$

'People are the real wealth of a nation. The basic objective of development is to create an enabling environment for people to enjoy long, healthy and creative lives. This simple truth...is often forgotten in the immediate concern with the accumulation of commodities and financial wealth. ${ }^{49}$ Indeed, regardless of the intellectual persuasiveness of the theory of comparative advantage, or any other theory, both trade and its economic gains remain a means to achieving far-reaching socioeconomic ends. The whole rhetoric about the virtues of trade would be empty unless it is shown that not only traders but also the whole society benefits from it. It should be remembered that even mercantilism has tremendous economic benefit for traders (at least for the powerful few), as Adam Smith observed. Thus, for the economic justification of free trade to be complete, the issue of equitable distribution of the returns of trade must be addressed. Economic efficiency, which is the chief justification for international trade agreements and institutions, explains why nations may benefit from liberalized trade; it does not, however, show how the aggregate economic growth translates into improved living standards for the society at large. It leaves the question of distribution unaddressed.

The quest for a fair distribution of the dividends of trade is not new. As discussed above, the normative and welfare aspects of trade were at the heart of classical trade theories. Indeed, the chief criticism against mercantilist theory was that it conflated means and ends in the sense that mere accumulation 'of gold or other treasures would not improve a country's living standards. ${ }^{50}$ In other words, the economic rationale for free trade is underpinned by the assumption that consumers ultimately benefit from free trade. Modern free trade theories too invariably argue based on the assumption that trade not only enhances the potential real national product of nations, but also ultimately leads to higher standards of

\footnotetext{
${ }^{47}$ WTO, Members Continue to Discuss on Proposal for Temporary IP Waiver in Response to COVID-19 (10 Dec 2020); https://www.wto.org/english/news_e/news20_e/trip_10dec20_e.htm

48 Reuters, WTO Delays Decision on Waiver on COVID-19 Drug, Vaccine Right (Dec 10, 2020); https://www.reuters.com/article/us-health-coronavirus-wto-idUSKBN28K2WL

${ }^{49}$ The United Nations Development Program (UNDP), Human Development Report (Oxford University Press, New York, 1990) 9

${ }^{50}$ Paul A. Samuelson and William D. Nordhaus, Economics (15 ${ }^{\text {th }}$ ed., McGraw-Hill, Inc. 1995) 692
} 
living - all over the world. ${ }^{51}$ Conversely, one of the strongest arguments against trade barriers, such as tariffs and quotas, is based on the social costs such barriers involve in terms of exposing consumers to higher price. ${ }^{52}$ As stated above, the WTO itself views trade as a means to enhance far-reaching socioeconomic objectives.

However, even if all the assumptions of the theory of comparative advantage perfectly hold, and thus potential real national product of nations is enhanced, there is no guarantee that the living standards of people will be improved. Indeed, the global economy has grown to record levels over the last several decades. Such economic growth is, however, eclipsed by an astonishing level of income and wealth disparity, between and within nations. ${ }^{53}$ Over the last four decades, the richest 0.1 percent has captured as much income as the bottom half of the global population. ${ }^{54}$ Since the pandemic hit, this obscene level of income inequality has reached new heights, as billionaires amassed trillions as the poor and the middle class struggle to make ends meet. ${ }^{55}$ Just a portion of the income captured by the top ten richest billionaires since the start of the pandemic is enough to pay for the COVID-19 vaccine for everyone. ${ }^{56}$ When it comes wealth inequality, the figure is even more extraordinary. In 2015, for example, just 62 individuals in the world held as much wealth as the bottom half of humanity. ${ }^{57}$ These disparities are systemic and structural both at national and international levels and are results of deliberately flawed economic and trade systems. Therefore, if trade is meant to help improve the standards of living of people, as the WTO claims, it is an imperative to put people at the center of trade agenda because standards of living are ultimately about people, not just national economic figures.

Individuals may not have standing or representation at the WTO. But power ultimately lies with the people. People may not be constantly protesting against the WTO any longer. Yet, that is not because despair and helplessness have vanished but rather because the social backlash has been redirected against national governments. The prevailing mood of helplessness, which resulted from spiraling inequalities has created a conducive ground for the rise of nationalism, exclusionary politics, and even neo-fascist movements. As a result, less people now live in freedom since 1995 (incidentally the year of WTO's founding) ${ }^{58}$ Domestic political pressure is forcing WTO members to revert back to protectionism. And this may not be the end. It is thus reasonable to conclude that a radicalre configuration of global trade is not only a question of equity but also an imperative for the preservation liberal democratic political order.

\footnotetext{
${ }^{51}$ Samuelson, supra $\mathrm{n} 8$ at 651

52 The argument is that by discouraging imports and thereby killing off the fruits of international division of labor, tariff and other trade barriers subject domestic consumer to increased prices and diminished choices.

53 'If unequal opportunities are large within many countries, they are truly staggering on a global scale.' World Bank, World Development Report:Equity and Development (Washington, D.C., 2006) 6; UNDP, Human Development Report (Oxford University Press, New York, 1999) 3

${ }^{54}$ World Inequality Report 2018. https://wir2018.wid.world/files/download/wir2018-full-report-english.pdf

${ }^{55}$ See P. Espinoza Revollo (2021). The Inequality Virus: Methodology note. Oxfam https://oxfamilibrary.openrepository.com/bitstream/handle/10546/621149/tb-inequality-virus-methodology-note-250121en.pdf

${ }^{56}$ Oxfam, The Inequality Virus: Bringing together a World Torn Apart by Coronavirus Though a Fair, Just and Sustainable Economy (January 2021), https://www.oxfam.org/en/research/inequality-virus

${ }^{57}$ Oxfam, An Economy for the 1\%: How Privilege and Power in the Economy Derive Extreme Inequality and How this can be Stopped (18 January 2016); available at: https://oi-files-d8-prod.s3.eu-west-2.amazonaws.com/s3fspublic/file_attachments/bp210-economy-one-percent-tax-havens-180116-en_0.pdf

${ }^{58}$ Freedom declined in 73 countries, representing 75 percent of the global population. Freedom House, Freedom in the World 2021: Democracy under Siege (2021), available at https://freedomhouse.org/sites/default/files/202102/FIW2021_World_02252021_FINAL-web-upload.pdf
} 


\section{CONCLUSIONS}

The case for free trade carries an intuitive appeal. Statistics also show that free trade normally increases aggregate economic welfare. However, in the final analysis, trade is just a means to an end. Its overall legitimacy must be judged by reference to its results in human terms; by the extent to which it helps create jobs, pull people out of the traps of poverty and deprivation, combat hunger and diseases, improve the quality and standards of living, and enhance domestic and global harmony. The tally of commodities manufactured and traded, grain produced, services rendered, or money invested would be meaningless it fails to enhance the above ends.

\section{REFERENCES}

1. Aristotle, The Nicomachean Ethics (5th ed., Kegan Paul, Trench, Trubner \&Co, London, 1893)

2. Bhuiyan, Sharif,National Law in WTO Law: Effectiveness and Good Governance in the WTO System (Cambridge, 2007)

3. Bhala, Raj,Resurrecting the Doha Round: Devilish Details, Grand Themes, and China Too, 45 Tex. Int'l L.J. (2009)

4. Copley, Stephen and Sutherland, Kathryn (eds.), Adam Smith's Wealth of Nations: New Interdisciplinary Essays (Manchester University press, Manchester, 1995)

5. Eide, Wenche Barth and Kracht, Uwe (eds.), Food and Human Rights in Development: Legal and Institutional Dimensions and Selected Topics (V.I, Intersentia, Antwerpen, Oxford, 2005)

6. Francioni,Francesco (ed.), Environment, Human Rights and International Trade (Hart Publishing, Oxford and Portland, Oregon, 2001)

7. Gomes, Leonard, The Economics and Ideology of Free Trade: A Historical Review (Edward Elgar, Cheltenham, UK., 2003)

8. Hestermeyer, Holger, Human Rights and the WTO: The Case of Patents and Access to Medicines (Oxford University Press, 2007)

9. Hopewell, Kristen, Breaking the WTO: How Emerging Powers Disrupted the Neoliberal Project (Stanford University Press, 2015)

10. Hudec, Robert E., Developing Countries in the GATT Legal System (Trade Policy Research Center, London, 1987)

11. Ishay, Micheline R., The History of Human Rights: From Ancient Times to the Globalization Era (University of California Press, Los Angeles, 2004)

12. Jackson, John H., The World Trading System: Law and Policy of International Relations (2 ${ }^{\text {nd }}$ ed., The MIT Press, Cambridge, Massachusetts, London, 1997)

13. Joseph, Sarah, Blame it on the WTO? A Human Rights Critique (Oxford University Press, New York, 2011)

14. Leary, Virginia A. and Warner, Daniel (eds.), Social Issues, Globalization and International Institutions (Martinus Nijhoff Publishers, Leiden, Boston, 2006)

15. Jannace, William and Tiffany, Paul, A New World Order: The Rule of Law, or the Law of Rulers? 42 Fordham International Law Journal (2019)

16. McNally, David,Political Economy and the Rise of Capitalism: A Reinterpretation (University of California Press, Berkley, 1988)

17. Samuelson, Paul A., Economics (1 $1^{\text {th }}$ ed., McGraw-Hill International Book Company, 1980) 
18. Sen, Amartya, Resources, Values and Development (Harvard University Press, Cambridge, Massachusetts, 1984)

19. Smith, Adam, An Inquiry into the Nature and Cause of the Wealth of Nations (Maruzen Company Limited, Tokyo,1776/1940)

20. Stiglitz, Joseph E. and Charlton, Andrew, Fair Trade for All: How Trade can Promote Development (Oxford University Press, Oxford, New York, 2005)

21. Summers, Clyde, The Battle in Seattle: Free Trade, Labor Rights, and Societal Values, 22 U. Pa. J. Int'l Econ. L (2001)

22. Yigzaw, Destaw A.,WTO Agricultural Trade and the Unfulfilled Promise of Development, 11 (2) SCJILB (2015)

23. Zamora, Stephen, Voting in International Economic Organizations, 74 A.J.I.L. (1980) 